\title{
LATENT VIRUS INFECTIONS
}

$\mathrm{T}$

THERE is increasing recognition that many virus infections, of animals, higher plants and bacteria, are present in the absence of overt symptoms and signs. Some of them become activated by the most various stimuli, and there is thus bred confusion as to the true causes of some diseases. Some insect viruses, when introduced into an insect which is not their natural host, may activate a virus latent in that host, starting off a serially transmissible disease which is not essentially caused by the virus first used. Study of these phenomena is made difficult by the lack of uniformity in the use by workers concerned of certain key words such as 'latent', 'inapparent', 'subclinical', 'masked'.

A symposium on "Latency and Masking in Viral and Rickettsial Infections" was held during September 4-6 on the University campus at Madison, Wisconsin. It was supported by the Rockefeller Foundation and the Wisconsin Alumni Research Foundation. About 225 people attended. The object was to exchange views on the mechanisms of latent infections and more particularly to try to reach some agreement concerning the proper use of relevant words. After the reading and discussing of the papers presented, there was, on each day, a more general debate under the ægis of a moderator, participated in both by a panel on the platform and by speakers from the body of the hall.

In an opening address, C. H. Andrewes (London) made a general survey of the field and put forward tentative suggestions as to the use of some important words. He emphasized, as did subsequent speakers, that the matter must be considered both at the hostparasite and the cell-virus level. He was followed by André Lwoff (Paris), who discussed lysogeny and the prophage-phage sequence as examples of latent infection of bacteria and its activation by ultra-violet rays and other stimuli. J. W. Beard (Durham, North Carolina) was much concerned about the use of the terms masking and masked virus. Shope first used the terms in virology for describing the state of affairs in which papillomata grew progressively in domestic rabbits, yet virus was hard to demonstrate except by indirect means. He believed that virus was present in a qualitatively changed state. Beard, on the other hand, held that the facts could be more simply explained by presence of virus in very small amounts : he felt that the term 'masked' should be either rigidly defined or abandoned. R. Dulbeceo (Pasadena) discussed temperate phages, which readily enter into a lysogenic relationship with bacteria; and the contrasting virulent phages which lead to lysis. He proposed the terms moderate, semi-moderate and virulent for describing corresponding relationships between the host-cells and viruses of animals and higher plants. Later, sub-moderato was preferred to semi-moderate and cytocidal to virulent.

R. J. Huebner (Bethesda) described latent infections with adenoviruses, salivary viruses and herpes; he felt that there was a virus-group in which presence of intranuclear inclusions was associated with a tendency to persisting infection. J. E. Hotehin (Albany, New York) reported studies of lymphocytic choriomeningitis in mice, extending Traub's classical findings. His work supported the idea that immunol- ogical tolerance might explain how, in mice infected in utero, persistent infection occurred, with absence of antibody formation or tissue reaction.

F. C. Bawden (Rothamsted) discussed the varying relations between higher plants and viruses, in particular the latency of paracrinkle virus in King Edward potatoes. He was inclined to make use of the word 'commensalism'.

Several workers described latent infections of viruses in tissue culture. T. T. Puck (Denver) spoke of cells chronically carrying Newcastle disease virus; the latent infection became manifest when they were plated on to a monolayer of highly susceptible irradiated cells. F. Deinhardt (Philadelphia) had studied similar cell lines carrying Newcastle disease virus or mumps virus. It appeared that only one in fifty of cells latently infected with Newcastle disease virus would liberate active virus, yet all were relatively resistant to infection with vesicular stomatitis virus. W. W. Ackerman (Ann Arbor) described somewhat similar experiments with poliomyelitisinfected cultures; and H. S. Ginsberg (Cleveland) spoke of experiments on latent infections of cultures with adenoviruses. H. R. Morgan (Rochester, N.Y.) had kept psittacosis virus in a latent state by starving his cultures : a good nutritive medium would activate the virus and apparently certain amino-acids and water-soluble vitamins were especially effective. C. B. Philip (Montana) spoke of a similar situation in ticks infected with rickettsiæ of rocky mountain spotted fever. The rickettsiæ were non-infectious in starved ticks but could be activated by feeding or incubation.

During discussion, Huebner mentioned a latent infection of HeLa cells with a virus which finally "turned his cultures into one giant cell". This virus was propagable in eggs, and antibodies were present in all human sera except those of early childhood.

In a final session for general appraisal and definition of terms, questions at issue were batted back and forth between the floor of the house and a panel consisting of Andrewes (moderator), Bawden, Beard, Dulbecco and Lwoff. Lwoff had prepared a document containing a number of definitions, and this served as a useful basis for discussion. Since practically every speaker earlier on had used the words 'latent', etc., in a different sense, it was surprising that a considerable measure of agreement was ultimately reached. There was in fact a fair consensus of opinion on the following points.

At the host-parasite level, 'inapparent infection' covers the whole field of infections which give no overt signs of their presence. 'Latent infection' denotes those cases of inapparent infection which are chronic and in which a certain host-virus equilibrium is established. No special word was recommended to describe inapparent infections of limited duration ('infection inapparente' in Nicolle's original sense), but it was recognized that the term 'subclinical' would continue to be used for many such infections of man and other species. (Most delegates were apparently very surprised to hear that the word 'clinical' originally had reference to 'bed'.) It was suggested that the term 'latent virus' be not used : confusion would seem inevitable if the same adjective 
were applied to 'infection' and to 'virus', since the meaning of 'latent' would necessarily be different in the two cases.

As regards the word 'masked' there seemed no possibility of obtaining agreement. It was suggested, therefore, that its use should not be encouraged but that 'occult virus' should be used instead. Among the definitions of occult provided by the Oxford dictionary were: "communicated only to the initiated; not apprehensible to the mind". The word 'occult' should cover "the cases where infective particles cannot be detected and in which the actual state of the virus cannot as yet be ascertained". Thus we might be unable to recover virus from an infected host but might be ignorant as to whether it was qualitatively altered or present in minute quantity or mixed with antibody. We should need a word to describe our state of ignorance : other more descriptive words could be used when the reason for the occult state had been discovered.

At the cell-virus level, it was agreed that a provirus, corresponding to prophage, had not been proved to exist, but that if and when other viruses were shown to pass through cycles like that of phage, the words 'provirus', 'vegetative virus' and 'infectious virus' would be appropriate to describe the corresponding stages.

Dulbecco's term 'moderate virus' was approved to denote a virus which grew in a cell while still permitting its continued survival and multiplication: 'cytocidal' described one which killed it: 'submoderate' covered intermediate cases. Clearly, some viruses are moderate for one cell-system, cytocidal for another: so the words are only relevant to particular virus-cell systems. It is important to note also that a virus may be cytocidal for some dispensable cells in a host, yet these may be at any one time few in number so that the infection as a whole is inapparent.

The proceedings of the symposium will be published shortly by the Burgess Press, Minneapolis.

C. H. ANDrewes

\section{BIOLOGY OF THE SALMON}

A SYMPOSIUM on the "Biology of the Salmon" was held on September 10 by Section D (Zoology) of the British Association meeting in Dublin.

Dr. A. E. J. Went opened the symposium with a paper entitled "Salmon Investigations in Ireland, with particular reference to the River Shannon". H.e pointed out that if it had been necessary to purchase salmon for investigation, progress would have been very slow owing to the great expense of obtaining fish; but fortunately a considerable amount of information can be obtained about an individual salmon by microscopic examination of its scales. The scale of a salmon is a life and birth certificate, and it was by this means that the late Rowland Southern in 1924 started his investigations into the salmon of the River Shannon which was then about to be harnessed for hydıo-electric purposes.

Southern's first paper in 1928 indicated in a general way the age and growth of salmon of the River Shannon in the years 1924-26 inclusive, and afterwards the investigations into the runs of fish in 1927 and 1928 were carried on by Went, using material from salmon taken in the ancient Lax Weir near Limerick. From 1941 onwards similar material has been collected annually from salmon taken in the Thomond Weir near Limerick.

Prior to the operation of the hydro-electric plant the Shannon was predominantly an early-salmon river; that is to say, the bulk of the fish had spent two or more years feeding in the sea. Taking the year 1928 as representative of the pre-hydro-electric scheme stocks and the year 1941 as representative of the post-hydro-electric scheme stocks, the differences in the stocks may be summarized briefly as follows: (1) the average age of the smolts was higher in 1941 (2.08 years) than in 1928 ( 1.98 years); (2) the grilse amounted to 75 per cent of the total run of 1941 , whereas in 1928 the figure was 24.7 per cent ; (3) in 1941, 70 per cent of the total run occurred in the month of June, whereas in 1928 that month's catch amounted to only 27.5 per cent of the total ; (4) the age of the fish in 1941 was approximately one year less than in 1928 ; (5) the average size of salmon entering the river in 1941 was much smaller than in 1928.

By a series of calculations it was found possible to estimate the relationship of the size of the 1928 and 1941 runs. By this method it could be shown that the grilse have not actually increased but they have remained relatively static over the years. Those age-groups of salmon which have spent two or more years feeding in the sea have been very much reduced and the present stocks of the River Shannon are about 30-40 per cent of those of the pre-hydroelectric scheme days. This change seems to be associated with the 'dewatering' of the main spawning beds for large salmon in the old channel of the Shannon between Killaloe and Limerick. This might account for the loss of the earlier running or larger fish. On the other hand, the Mulcair River, which is the major spawning tributary of the Shannon to-day, always was the major spawning ground for the smaller fish.

Adequate material has now been collected annually from 1941 to date and it has been possible to follow the changes in the sizes of the stocks and to estimate the yield (as adult fish) from a number of brood years from 1942 to 1951 . Variations in the number of fish derived from the different brood years during this period have ranged from 16,100 for 1950 to 6,400 for 1942 .

At this stage Miss E. Twomey took up the story with her paper, "The Age and Growth of Irish Salmon". She gave the results of investigations into the age and growth of the salmon of various Irish rivers, again using collections of salmon scales and data relating to the weight, length and date of capture of the fish concerned. Salmon in Irish rivers spend 1-4 years before migrating to the sea for the first time. The majority of fish, however, spend two years in the fresh water, the one-year old smolts generally being next in importance. Only a few four-year olds have been identified from Irish rivers.

Two types of smolts have been identified in Irish rivers, namely, those which show little or no growth in fresh water in the spring prior to the smolt descent, and those which showed considerable growth. These types have been described by Went as type $A$ and type $B$ smolts, respectively. All the one-year smolts were of type $B$, and in the older smolt classes both types were found ; the proportion of type $A$ increased gradually as the smolt age is ascended. 